\title{
Diagnosing $\mathrm{CO}_{2}$ fluxes in the upwelling system off the Oregon-California coast
}

\author{
Z. Cao ${ }^{1, *}$, M. Dai ${ }^{1}$, W. Evans ${ }^{2,3}$, J. Gan ${ }^{4}$, and R. Feely ${ }^{2}$ \\ ${ }^{1}$ State Key Laboratory of Marine Environmental Science, Xiamen University, Xiamen, China \\ ${ }^{2}$ Pacific Marine Environmental Laboratory, National Oceanic and Atmospheric Administration, Seattle, Washington, USA \\ ${ }^{3}$ Ocean Acidification Research Center, School of Fisheries and Ocean Sciences, University of Alaska Fairbanks, \\ Fairbanks, Alaska, USA \\ ${ }^{4}$ Division of Environment and Department of Mathematics, Hong Kong University of Science and Technology, \\ Kowloon, Hong Kong SAR, China \\ *now at: GEOMAR Helmholtz Center for Ocean Research Kiel, Kiel, Germany
}

Correspondence to: M. Dai (mdai@xmu.edu.cn)

Received: 8 March 2014 - Published in Biogeosciences Discuss.: 21 May 2014

Revised: 30 September 2014 - Accepted: 8 October 2014 - Published: 24 November 2014

\begin{abstract}
It is generally known that the interplay between the carbon and nutrients supplied from subsurface waters via biological metabolism determines the $\mathrm{CO}_{2}$ fluxes in upwelling systems. However, quantificational assessment of such interplay is difficult because of the dynamic nature of both upwelling circulation and the associated biogeochemistry. We recently proposed a new framework, the Oceandominated Margin (OceMar), for semi-quantitatively diagnosing the $\mathrm{CO}_{2}$ source/sink nature of an ocean margin over a given period of time, highlighting that the relative consumption between carbon and nutrients determines if carbon is in excess (i.e., $\mathrm{CO}_{2}$ source) or in deficit (i.e., $\mathrm{CO}_{2}$ sink) in the upper waters of ocean margins relative to their off-site inputs from the adjacent open ocean. In the present study, such a diagnostic approach based upon both couplings of physics-biogeochemistry and carbon-nutrients was applied to resolve the $\mathrm{CO}_{2}$ fluxes in the well-known upwelling system off Oregon and northern California of the US west coast, using data collected along three cross-shelf transects from the inner shelf to the open basin in spring/early summer 2007. Through examining the biological consumption on top of the water mass mixing revealed by the total alkalinity-salinity relationship, we successfully predicted and semi-analytically resolved the $\mathrm{CO}_{2}$ fluxes showing strong uptake from the atmosphere beyond the nearshore regions. This $\mathrm{CO}_{2}$ sink nature primarily resulted from the higher utilization of nutrients relative to dissolved inorganic carbon (DIC) based on
\end{abstract}

their concurrent inputs from the depth. On the other hand, the biological responses to intensified upwelling were minor in nearshore waters off the Oregon-California coast, where significant $\mathrm{CO}_{2}$ outgassing was observed during the sampling period and resolving $\mathrm{CO}_{2}$ fluxes could be simplified without considering DIC/nutrient consumption, i.e., decoupling between upwelling and biological consumption. We reasoned that coupling physics and biogeochemistry in the OceMar model would assume a steady state with balanced DIC and nutrients via both physical transport and biological alterations in comparable timescales.

\section{Introduction}

The contemporary coastal ocean, characterized by high primary productivity due primarily to the abundant nutrient inputs from both river plumes and coastal upwelling, is generally seen as a significant $\mathrm{CO}_{2}$ sink at the global scale (Borges et al., 2005; Cai et al., 2006; Chen and Borges, 2009; Laruelle et al., 2010; Borges, 2011; Cai, 2011; Dai et al., 2013). However, mechanistic understanding of the coastal ocean carbon cycle remains limited, leading to the unanswered question of why some coastal systems are sources while others are sinks of atmospheric $\mathrm{CO}_{2}$ in a given timescale. We recently proposed a new framework, the Ocean-dominated Margin (OceMar), for better shaping the concept of a coastal ocean carbon 
study (Dai et al., 2013). This framework highlights the importance of the boundary process between the open ocean and the ocean margin, and proposes a semi-analytical diagnostic approach to resolve sea-air $\mathrm{CO}_{2}$ fluxes over a given period of time. The approach invokes an establishment of the water mass mixing scheme in order to define the physical transport of, or the conservative portion of carbon and nutrients, from the adjacent open ocean, and the constraint of the biogeochemical alteration of these non-local inputs in the upper waters of ocean margins. The water mass mixing scheme is typically revealed using conservative chemical tracers such as total alkalinity (TAlk) and/or dissolved calcium ions $\left(\mathrm{Ca}^{2+}\right)$ to bypass the identification of end members associated with individual water masses that often possess high complexity in any given oceanic regime. The constraint of the biogeochemical alteration can then be estimated as the difference between the predicted values based on conservative mixing between end members and the field-measured values. The relative consumption between dissolved inorganic carbon (DIC) and nutrients determines if DIC is in excess or in deficit relative to the off-site input. Such excess DIC will eventually be released to the atmosphere through sea-air $\mathrm{CO}_{2}$ exchange. Using two large marginal seas, the South China Sea (SCS) and the Caribbean Sea (CS), as examples, we have successfully predicted, via evaluating DIC and nutrient mass balance, the $\mathrm{CO}_{2}$ outgassing that is consistent with field observations (Dai et al., 2013). However, the OceMar concept and the diagnostic approach have not been verified on upwelling systems that can be either sources (e.g., Friederich et al., 2002; Torres et al., 2003; Fransson et al., 2006) or sinks (e.g., Borges and Frankignoulle, 2002; Santana-Casiano et al., 2009; Evans et al., 2012) of atmospheric $\mathrm{CO}_{2}$. While it is generally known that the interplay between the nutrients and DIC supplied from subsurface waters via biological metabolism would determine the $\mathrm{CO}_{2}$ fluxes in upwelling systems, quantificational assessment of such interplay is difficult because of the dynamic nature of both upwelling circulation and the associated biogeochemistry.

Our study therefore chose the upwelling system offshore Oregon and northern California, for examining the $\mathrm{CO}_{2}$ flux dynamics during the upwelling season through our proposed mass balance approach associated with carbon/nutrient coupling. The system under study is part of the eastern boundary current in the North Pacific (Fig. 1). While strong equatorward winds in spring/summer drive offshore Ekman transport at the surface over the coastal waters, the carbon- and nutrient-rich deep water is transported shoreward and upward over the shelf to compensate for the offshore transport in the surface layer (Huyer, 1983; Kosro et al., 1991; Allen et al., 1995; Federiuk and Allen, 1995; Gan and Allen, 2002). Outcrops of waters from depths of 150-200 m are frequently observed nearshore the Oregon-California shelf, where the surface partial pressure of $\mathrm{CO}_{2}\left(p \mathrm{CO}_{2}\right)$ can reach levels near $1000 \mu \mathrm{atm}$. This water is then transported seaward and south-

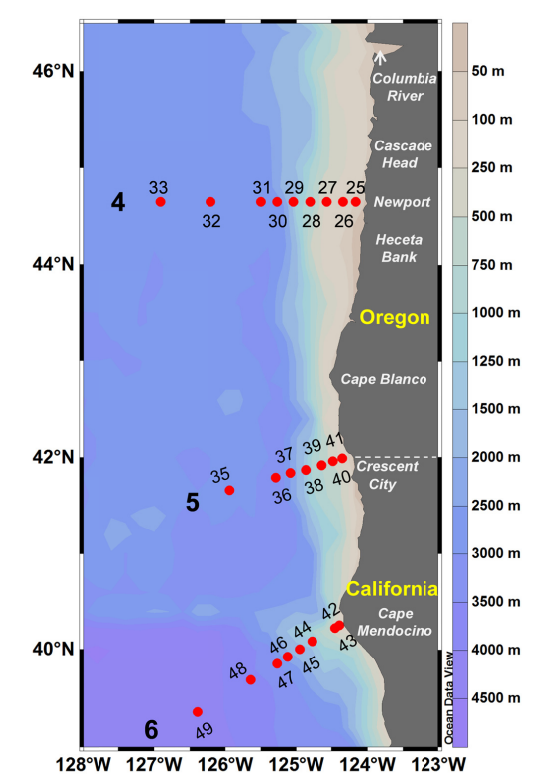

Figure 1. Map of offshore Oregon and northern California (US west coast) showing the topography and the locations of sampling stations along transects 4, 5 and 6 in spring/early summer 2007.

ward while the $p \mathrm{CO}_{2}$ is drawn down by biological productivity, and can reach values down to $\sim 200 \mu \mathrm{atm}$, far below the atmospheric $p \mathrm{CO}_{2}$ value (Hales et al., 2005, 2012; Feely et al., 2008; Evans et al., 2011). Such a dramatic decrease in seawater $p \mathrm{CO}_{2}$ may be due to the fact that the complete utilization of the preformed nutrients in upwelled waters exceeds their corresponding net DIC consumption, leading to the area off Oregon and northern California acting as a net sink of atmospheric $\mathrm{CO}_{2}$ during the upwelling season (Hales et al., 2005, 2012). On the other hand, Evans et al. (2011) suggest that the spring/early summer undersaturated $p \mathrm{CO}_{2}$ conditions in some offshore areas result from non-local productivity associated with the Columbia River (CR) plume, which transports $\sim 77 \%$ of the total runoff from western North America to the Pacific Ocean (Hickey, 1989).

In this context, the Oregon-California shelf in the upwelling season could be a potential OceMar-type system, with the majority of DIC and nutrients in the upper layer originating from the non-local deep waters in the subtropical gyre of the eastern North Pacific (eNP), though riverine inputs might complicate the application of the OceMar framework. On the other hand, the upper waters in offshore areas beyond the upwelling circulation on the Oregon-California shelf would be largely fed by on-site deep waters via vertical mixing, with minor influence of the CR plume. 

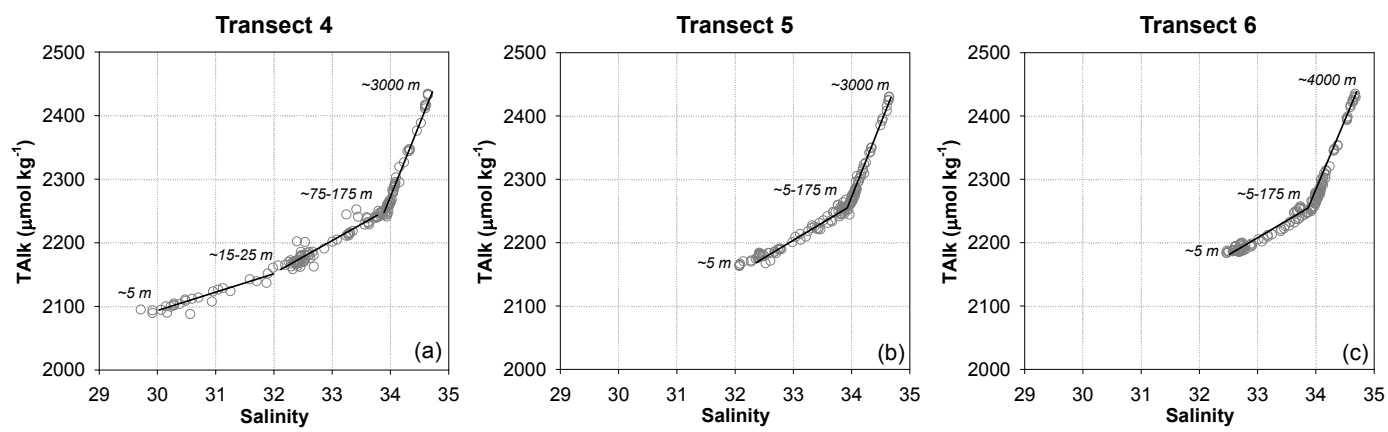

Figure 2. Total alkalinity versus salinity throughout the entire water column of sampling stations along transects 4 (a), 5 (b) and 6 (c) off Oregon and northern California in spring/early summer 2007. The solid lines indicate various linear relationships observed on each transect. The numbers in italics denote the sampling depth/depth range of the endpoints of each line.

\section{Study area and data source}

\subsection{California Current system and upwelling circulation}

The upwelling circulation off Oregon and northern California is linked with the eastern boundary current, the California Current (CC), occupying the open basin of the eNP (Barth et al., 2000). The CC is a broad and weak surface current $(0-200 \mathrm{~m})$ which carries low-salinity/low-temperature water equatorward from the sub-Arctic Pacific (Lynn and Simpson, 1987). The deeper-lying California Undercurrent (CUC, $150-300 \mathrm{~m}$ ), which has relatively high salinity and temperature, originates in the eastern equatorial Pacific and flows poleward inshore along the west coast of North America (Thomson and Krassovski, 2010). The CC system is characterized by coastal upwelling in spring/summer, during which waters primarily composed of the CC are transported upward from the depths of 150-200 m towards the nearshore surface off the Oregon-California coast (Castro et al., 2001).

Both field observations and modeling studies (Oke et al., 2002; Gan and Allen, 2005) show that the upwelling circulation pattern in the study area differs significantly between north and south of Newport (Fig. 1). North of Newport between 45.0 and $45.5^{\circ} \mathrm{N}$ with a relatively straight coastline and narrow shelf, the alongshore uniform bottom topography generally results in typical upwelling circulation with a southward coastal jet close to shore at Cascade Head (Fig. 1). Over the central Oregon shelf between 43.5 and $45.0^{\circ} \mathrm{N}$, the highly variable bottom topography over Heceta Bank (Fig. 1) largely influences the upwelling circulation, leading to a complex three-dimensional flow pattern with offshore shifting of the coastal jet and development of northward flow inshore. At the coast along the southern part of Oregon and northern California between 39.0 and $43.0^{\circ} \mathrm{N}$, an enhancement of coastal upwelling, jet separation and eddy formation are observed to be associated with interactions of the windforced coastal currents with Cape Blanco (Fig. 1) (Barth and Smith, 1998; Gan and Allen, 2005, and references therein).

\subsection{Data source}

Our data sets were based on the online-published carbonate system and nutrient data collected along three transects off Oregon and northern California during the first North American Carbon Program (NACP) West Coast Cruise in spring/early summer (11 May-14 June) 2007 (http://cdiac.ornl.gov/oceans/Coastal/NACP_West.html; Feely et al., 2008; Feely and Sabine, 2011). Transect 4 (stations 25-33 from nearshore to offshore) is located off Newport, Oregon. Transect 5 (stations 41-35 from nearshore to offshore) is located off Crescent City near the Oregon-California border. Transects 6 (stations 42-49 from nearshore to offshore) is located off Cape Mendocino, California. The majority of the offshore stations on all transects were located in the open subtropical gyre of the eNP (Fig. 1).

\section{Results and discussion}

The region under study is highly dynamic, potentially involving coastal upwelling, the CR plume and pelagic waters mixed by various Pacific water masses (Hill and Wheeler, 2002). Instead of accounting for all of the water masses contributing to the $\mathrm{CC}$ system, the mixing scheme in the upper waters along the three transects was examined via the total alkalinity-salinity (TAlk-Sal) relationship obtained during the sampling period so as to quantify the conservative portion of DIC and nitrate $\left(\mathrm{NO}_{3}\right)$. The end members were therefore identified under this relationship, which might have experienced physical or biological alterations from their original water masses such as the CR and the CC. Subsequently, the biologically consumed DIC and $\mathrm{NO}_{3}$ were quantified as the difference between their conservative values predicted from the derived end-member mixing and the corresponding field measurements. Finally, the $\mathrm{CO}_{2}$ source/sink nature of the upper waters off Oregon and northern California during the sampling period was diagnosed via a mass balance approach by estimating the relative consumption between DIC 
and $\mathrm{NO}_{3}$, and a simple sensitivity analysis was performed to test the robustness of the approach.

\subsection{TAlk-Sal relationship}

\subsubsection{Throughout the entire water column off Oregon and northern California}

Three generally linear relationships between TAlk and salinity were observed throughout the entire water column along transect 4 (Fig. 2a). The first one was for waters with salinity lower than $\sim 32.0$ (corresponding to a depth of $\sim 15-25 \mathrm{~m}$ ), which were significantly influenced by the $\mathrm{CR}$ plume. The second one was for waters composed primarily of the $\mathrm{CC}$ with salinity between $\sim 32.0$ and $\sim 33.9$, including those immediately below the surface buoyant layer at stations 26-32 and the surface waters at the outermost station 33 (Fig. 1). The higher-end salinity value of $\sim 33.9$ corresponded to a depth range of $\sim 75-175 \mathrm{~m}$, composed possibly of the upwelled high-salinity CUC waters. At station 27 (water depth $\sim 170 \mathrm{~m}$ ) for instance, salinity at depths of $\sim 130$ and $\sim 160 \mathrm{~m}$ reached $\sim 34.0$ with TAlk values of $\sim 2260 \mu \mathrm{mol} \mathrm{kg}^{-1}$, which were even higher than those of offshore waters at $\sim 175 \mathrm{~m}\left(\sim 2250 \mu \mathrm{mol} \mathrm{kg}{ }^{-1}\right)$. These two data points were thus located on the third linear relationship for waters with salinity higher than $\sim 33.9$, the slope of which became much steeper, mainly reflecting the mixing between the approaching CUC and deep waters in the subtropical gyre of the eNP (Fig. 2a).

All salinity values, including surface samples on transects 5 and 6, were higher than 32.0 (Fig. $2 \mathrm{~b}$ and c). With minor influence of the CR plume, the TAlk-Sal relationship displayed two generally linear phases throughout the entire water column along both transects, while the TAlk and salinity endpoints of each were comparable to those of the latter two observed on transect 4 (i.e., the linear phases for waters with salinity between $\sim 32.0$ and $\sim 33.9$ and with salinity higher than $\sim 33.9$; Fig. 2a). Note that the turning point with salinity of $\sim 33.9$ corresponded to a wider depth range of $\sim 5-175 \mathrm{~m}$ (Fig. 2b and c), resulting from the most intensive upwelling on transects 5 and 6 bringing deep waters to the nearshore surface (Feely et al., 2008).

As suggested by the generally linear TAlk-Sal relationships, surface waters beyond the CR plume and waters immediately below the surface buoyant layer were directly linked to the underlying waters to the depth of $\sim 175 \mathrm{~m}$. We thus took a closer look at the TAlk-Sal relationship in the upper $175 \mathrm{~m}$ waters off Oregon and northern California.

\subsubsection{In the upper $175 \mathrm{~m}$ waters off Oregon and northern California}

In the upper $175 \mathrm{~m}$ waters along transect 4 , the linear regression for waters with salinity lower than $\sim 32.0$ had an intercept of $\sim 1200 \mu \mathrm{mol} \mathrm{kg}{ }^{-1}$. This value agreed well with the observed TAlk of $\sim 1000 \mu \mathrm{mol} \mathrm{kg}^{-1}$ in the mainstream of the CR (Park et al., 1969b; Evans et al., 2013). The other linear regression for waters with salinity between $\sim 32.0$ and $\sim 33.9$ had a smaller intercept of $\sim 500 \mu \mathrm{mol} \mathrm{kg}{ }^{-1}$, implying a smaller contribution from the CR plume (Fig. 3a). Exceptions were observed at the shallowest station 25 (water depth $\sim 50 \mathrm{~m}$ ) and the deepest station 33 (water depth $\sim 2900 \mathrm{~m}$ ). The TAlk-Sal relationship completely followed the second phase for the upper $175 \mathrm{~m}$ waters at station 33 (Fig. 3a), suggesting a small fraction of the CR plume even in the surface waters of this outermost station on transect 4 . On the other hand, data points of the two variables were not well correlated throughout the entire water column of station 25 and fell off both regression lines (Fig. 3a). The water mass mixing at this innermost station was not as straightforward, despite minor freshwater admixture as suggested by the high surface salinity of $>32.0$.

The TAlk-Sal relationship in the upper $175 \mathrm{~m}$ waters on transects 5 and 6 displayed two similar phases. One was the linear regression for stations 35-38 (deeper than $\sim 800 \mathrm{~m}$ ) and stations $45-49$ (deeper than $\sim 1400 \mathrm{~m}$ ), with slope and intercept values comparable to the second phase observed on transect 4 . The other was the linear regression for the three shallow stations on both transects largely influenced by coastal upwelling (Feely et al., 2008) (Fig. 3b and c). This phase was not clearly seen from the full TAlk-Sal plot (Fig. $2 \mathrm{~b}$ and c), as the salinity in the upper $175 \mathrm{~m}$ waters at stations 39 and 44 as well as in the entire water column of stations 40-43 varied within a much smaller range of $\sim 33.3-\sim 34.0$. The negligible intercepts of this TAlk-Sal regression suggested insignificant freshwater input with zero solutes to the intensive upwelling zone off Oregon and northern California (Fig. 3b and c).

All phases shown in Fig. 3 displayed good linear TAlk-Sal relationships $(r>0.94)$, indicating an overall twoend-member mixing scheme for each phase. Although the non-conservativity of TAlk existed, it was not that significant as seen by the deviations of a few data points from each linear regression (Fig. 3). As a matter of fact, Fassbender et al. (2011) estimated that the contribution from $\mathrm{CaCO}_{3}$ dissolution to the TAlk addition in the surface mixed layer on transect 5 was $<10 \mu \mathrm{mol} \mathrm{kg}^{-1}$ ( $<0.5 \%$ of their absolute contents in seawater) and well near the analytical precision. Such small non-conservative portions would not compromise the application of TAlk as a conservative tracer. Note that the two-end-member mixing was not spatially homogeneous in the upper waters off Oregon and northern California during the sampling period. The surface waters at stations 26-32 on transect 4 were imprinted by the CR plume with a salinity around $\sim 30.0$. During the transport from the mouth of the CR estuary, the plume water increasingly mixed with adjacent oceanic waters, largely feeding its pathway. However, the majority of DIC and nutrients in waters immediately below the buoyant layer, as well as in surface waters at station 33 and possibly at station 25 , originated from deep 

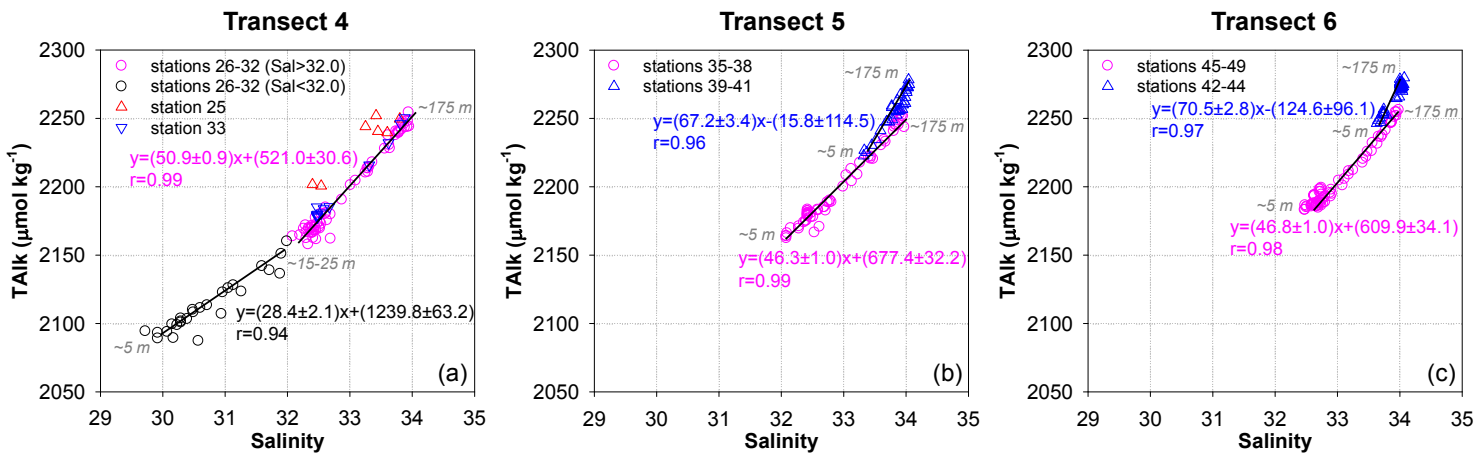

Figure 3. Total alkalinity versus salinity (TAlk-Sal relationship) in the upper $175 \mathrm{~m}$ waters of sampling stations along transects 4 (a), 5 (b) and 6 (c) off Oregon and northern California in spring/early summer 2007. The solid lines as well as the equations (in accordance with the symbol colors) indicate the linear regression analyses of the TAlk-Sal relationship for various stations. The numbers in italics denote the sampling depth/depth range of the endpoints of each line. In (a), the TAlk-Sal relationship at station 26-32 displayed two phases for waters with salinities lower and higher than $\sim 32.0$. The surface waters at these stations were imprinted by the Columbia River plume. The data points of bottom waters at stations $26(\sim 75 \mathrm{~m})$ and $27(\sim 130$ and $\sim 160 \mathrm{~m})$ were not included, as they were located on the third linear relationship shown in Fig. 2a. In (b) and (c), stations 39-41 and stations 42-44 were largely influenced by coastal upwelling.

waters, brought up through coastal upwelling and/or vertical mixing. The influence of the CR plume still occurred but was diluted by other freshwater masses such as rainwater, suggesting a mixing scheme between the deep water in the subtropical gyre of the eNP and a combined freshwater end member (Park, 1966, 1968). Such mixing was also applicable to the surface waters at stations $35-38$ on transect 5 and stations 45-49 on transect 6 . On the other hand, the upper $175 \mathrm{~m}$ waters or the entire water column at stations 39-44 resulted from a simple two-end-member mixing between the upwelling source water and the rainwater with zero solutes, pointing to an apparent OceMar-type system.

\section{2 $\Delta \mathrm{DIC}$ and $\Delta \mathrm{NO}_{3}$ in the upper waters off Oregon and northern California}

The defined mixing schemes enabled us to estimate the nonconservative portion of DIC $(\triangle \mathrm{DIC})$ and $\mathrm{NO}_{3}\left(\Delta \mathrm{NO}_{3}\right)$ in the upper waters off Oregon and northern California following Dai et al. (2013):

$\Delta \mathrm{DIC}=\mathrm{DIC}^{\mathrm{cons}}-\mathrm{DIC}^{\mathrm{meas}}$,

$\Delta \mathrm{NO}_{3}=\mathrm{NO}_{3}^{\text {cons }}-\mathrm{NO}_{3}^{\text {meas }}$,

$X^{\mathrm{cons}}=\frac{\mathrm{Sal}^{\text {meas }}}{\mathrm{Sal}^{\text {ref }}} \cdot\left(X^{\mathrm{ref}}-X^{\mathrm{eff}}\right)+X^{\mathrm{eff}}$.

The superscripts "cons" and "meas" in Eqs. (1) and (2) denote conservative-mixing-induced and field-measured values. In Eq. (3), $X$ represents DIC or $\mathrm{NO}_{3}$, while $\mathrm{Sal}^{\text {meas }}$ is the Conductivity-Temperature-Depth (CTD) recordermeasured salinity. Sal ${ }^{\text {ref }}$ and $X^{\text {ref }}$ are the reference salinity and concentration of DIC or $\mathrm{NO}_{3}$ for the deep water end member, which are the averages of all $\sim 175 \mathrm{~m}$ samples from stations involved in each mixing scheme. Specifically, for waters immediately below the surface buoyant layer at stations $27-32$ and waters in the surface mixed layer at stations 25 and 33 on transect 4, the deep water end-member values of the reference salinity and concentrations of DIC or $\mathrm{NO}_{3}$ were the averages of $\sim 175 \mathrm{~m}$ samples from stations 28-33 (Fig. 1). On transects 5 and 6, the preformed salinity, DIC and $\mathrm{NO}_{3}$ values for waters in the surface mixed layer at stations 35-38 and at stations 45-49 were the averages of $\sim 175 \mathrm{~m}$ samples of these stations. For the upper waters influenced by the intensified upwelling at stations 39-41 and stations 42-44, the deep water end member was selected as the $\sim 175 \mathrm{~m}$ water at station 39 and at station 44 (Fig. 1).

The $X^{\text {eff }}$ in Eq. (3) denotes the effective concentration of DIC or $\mathrm{NO}_{3}$ sourced from the freshwater input to various zones off Oregon and northern California. Since rainwater was assumed to have no solutes, both DIC ${ }^{\text {eff }}$ and $\mathrm{NO}_{3}^{\text {eff }}$ would be zero for waters in the surface mixed layer of stations $39-41$ on transect 5 and stations $42-44$ on transect 6. On the other hand, the estimation of $X^{\text {eff }}$ associated with the CR followed the method for the OceMar case study of the CS, which has a noticeable DIC ${ }^{\text {eff }}$ from the combination of the Amazon River and the Orinoco River (Dai et al., 2013).

Since bicarbonate dominates other $\mathrm{CO}_{2}$ species and other alkalinity components, DIC concentrations in the mainstream of the CR are numerically similar to TAlk, which are also around $\sim 1000 \mu \mathrm{mol} \mathrm{kg}^{-1}$ (Park et al., 1969a, 1970). This value was taken as the DIC end member of the CR. The $\mathrm{NO}_{3}$ end-member value was selected as $15 \mu \mathrm{mol} \mathrm{kg} \mathrm{kg}^{-1}$ based on recent years' observations in May and June at station SATURN-05 established in the upstream CR (database of the Center for Coastal Margin Observation and Prediction; 
http://www.stccmop.org/datamart/). Assuming that the biological consumption of DIC and $\mathrm{NO}_{3}$ in the CR plume followed the Redfield ratio (Redfield et al., 1963), the DIC removal was estimated to be $\sim 100 \mu \mathrm{mol} \mathrm{kg}{ }^{-1}$ (approximately $15 \times 106 / 16$ ), while $\mathrm{NO}_{3}$ was rapidly consumed along the pathway of the CR plume and generally depleted in the area beyond the plume (Aguilar-Islas and Bruland, 2006; Lohan and Bruland, 2006). As a consequence, the complete DIC ${ }^{\text {eff }}$ and $\mathrm{NO}_{3}^{\text {eff }}$ in the upper waters from the $\mathrm{CR}$ would be $\sim 900$ and $\sim 0 \mu \mathrm{mol} \mathrm{kg}^{-1}$.

If the combined freshwater end member was a mixture of the $\mathrm{CR}$ and the rainwater with zero solutes, the intercept values of $521.0 \pm 30.6$ (Fig. 3a), $677.4 \pm 32.2$ (Fig. 3b) and $609.9 \pm 34.1$ (Fig. 3c) derived from the TAlk-Sal regression would indicate that the $\mathrm{CR}$ fractions were $\sim 50$, $\sim 65$ and $\sim 60 \%$ (approximately 500/1000, 650/1000 and $600 / 1000$ taking $\sim 1000 \mu \mathrm{mol} \mathrm{kg}{ }^{-1}$ as the TAlk end-member value of the CR, Park et al., 1969b; Evans et al., 2013). The DIC ${ }^{\text {eff }}$ from the freshwater input was thus estimated to be $\sim 450 \mu \mathrm{mol} \mathrm{kg}^{-1}$ (approximately $900 \times 50 \%$ ) for waters immediately below the surface buoyant layer at stations $27-32$ and waters in the surface mixed layer at stations 25 and 33 on transect 4 , which was slightly lower than the $\sim 585 \mu \mathrm{mol} \mathrm{kg}^{-1}$ (approximately $900 \times 65 \%$ ) and the $\sim 540 \mu \mathrm{mol} \mathrm{kg}^{-1}$ (approximately $900 \times 60 \%$ ) for waters in the surface mixed layer at stations $35-38$ on transect 5 and at stations $45-49$ on transect 6 , respectively. The $\mathrm{NO}_{3}^{\text {eff }}$ in any combined freshwater end member was zero.

Note that numerous small mountain rivers are distributed along the Oregon-California coast, which might also dilute the CR plume, inducing the lower intercept of the TAlk-Sal regression observed on the three transects (Fig. 3). The average wintertime discharge from the Oregon Coast Range rivers is estimated to be $\sim 2570 \mathrm{~m}^{3} \mathrm{~s}^{-1}$ (Wetz et al., 2006), which is more than an order of magnitude higher than that in the summer (Colbert and McManus, 2003; Sigleo and Frick, 2003). However, the CR discharge in May to June 2007 reached its maximum of $\sim 15000 \mathrm{~m}^{3} \mathrm{~s}^{-1}$ (Evans et al., 2013), which should be approximately 2 orders of magnitude higher than the discharge of small rivers. This significant contrast would suggest that inputs from small rivers should be negligible compared to the CR plume. In particular, inputs from small rivers are normally restricted to a narrow band near the coast, whereas the research domain of this study extended to the open subtropical gyre of the eNP. Even the surface salinity at the innermost stations (i.e., station 25 on transect 4 , station 41 on transect 5 and station 42 on transect 6; Fig. 1) was as high as $\sim 32.5, \sim 33.9$ and $\sim 34.0$, which would rule out the influence of small rivers.

\subsection{Evaluating the $\mathrm{CO}_{2}$ source/sink nature in the upper waters off Oregon and northern California}

The coupling of DIC and $\mathrm{NO}_{3}$ dynamics could then be examined based on the classic Redfield ratio of
$\mathrm{C}: \mathrm{N}=106: 16=6.6$ (Redfield et al., 1963). Positive values of the difference between $\triangle \mathrm{DIC}$ and $6.6 \Delta \mathrm{NO}_{3}$ $\left(\triangle \mathrm{DIC}-6.6 \Delta \mathrm{NO}_{3}\right)$ suggested a $\mathrm{CO}_{2}$ source term since "excess $\triangle$ DIC" was removed by $\mathrm{CO}_{2}$ degassing into the atmosphere. In contrast, negative $\Delta \mathrm{DIC}-6.6 \Delta \mathrm{NO}_{3}$ suggested that "deficient $\triangle \mathrm{DIC}$ " was supplied via the atmospheric $\mathrm{CO}_{2}$ input to the ocean, representing a $\mathrm{CO}_{2}$ sink. Such net $\mathrm{CO}_{2} \mathrm{ex}-$ change between the seawater and the atmosphere was further quantified as the sea-air difference of $p \mathrm{CO}_{2}\left(\Delta p \mathrm{CO}_{2}\right)$ via the Revelle factor (RF), which is referred to as the fractional change in seawater $\mathrm{CO}_{2}$ over that of DIC at a given temperature, salinity and alkalinity, and indicates the ocean's sensitivity to an increase in atmospheric $\mathrm{CO}_{2}$ (Revelle and Suess, 1957; Sundquist et al., 1979). Because $p \mathrm{CO}_{2}$ and $\mathrm{CO}_{2}$ are proportional to each other, the RF can be illustrated as:

$\mathrm{RF}=\frac{\partial p \mathrm{CO}_{2} / p \mathrm{CO}_{2}}{\partial \mathrm{DIC} / \mathrm{DIC}}$.

Here, $\partial p \mathrm{CO}_{2}$ and $\partial \mathrm{DIC}$ are the fractional changes of $p \mathrm{CO}_{2}$ and DIC in the surface seawater. In a simplified way and as an approximation, $\partial \mathrm{DIC}$ equals $\Delta \mathrm{DIC}-6.6 \Delta \mathrm{NO}_{3}$, which is solely achieved through sea-air $\mathrm{CO}_{2}$ exchange in the OceMar framework, implying that $\partial p \mathrm{CO}_{2}$ may represent the sea-air $\Delta p \mathrm{CO}_{2}$. Given an initial balance of $\mathrm{CO}_{2}$ between the seawater and the atmosphere, the sea-air $\Delta p \mathrm{CO}_{2}$ is obtained by

$$
\begin{gathered}
\text { Sea-air } \Delta p \mathrm{CO}_{2}=\partial p \mathrm{CO}_{2}=\mathrm{RF} \cdot p \mathrm{CO}_{2} \cdot \frac{\partial \mathrm{DIC}}{\mathrm{DIC}} \\
=\mathrm{RF} \cdot p \mathrm{CO}_{2}^{\mathrm{air}} \cdot \frac{\Delta \mathrm{DIC}-6.6 \Delta \mathrm{NO}_{3}}{\mathrm{DIC}} .
\end{gathered}
$$

As shown in Fig. 4, the estimated $\Delta \mathrm{DIC}-6.6 \Delta \mathrm{NO}_{3}$ values and their corresponding sea-air $\Delta p \mathrm{CO}_{2}$ values in the upper waters off Oregon and northern California were overall below zero, suggesting a significant $\mathrm{CO}_{2}$ sink nature in the upwelling season.

\subsubsection{Transect 4}

On transect 4 off Newport, the average value of $\Delta \mathrm{DIC}-6.6 \Delta \mathrm{NO}_{3}$ was $-23 \pm 2 \mu \mathrm{mol} \mathrm{kg} \mathrm{kg}^{-1}$ in waters immediately below the surface buoyant layer at stations 27-32, which equaled the average value for the surface mixed layer at station 33 (Fig. 4a). Note that we were not able to derive values of $\triangle \mathrm{DIC}-6.6 \Delta \mathrm{NO}_{3}$ at station 26 where $\mathrm{NO}_{3}$ data were not available. Although located at different depths, the two water parcels experienced similar physical mixing and biogeochemical modifications inducing the same $\mathrm{CO}_{2}$ signature. The former water mass should work as a $\mathrm{CO}_{2}$ sink when in contact with the atmosphere before or after the passage of the episodic CR plume. The average sea-air $\triangle p \mathrm{CO}_{2}$ resulting from the combined deficient $\triangle \mathrm{DIC}$ was $-54 \pm 4 \mu \mathrm{atm}$ (Fig. 3a). Given the atmospheric $p \mathrm{CO}_{2}$ of $\sim 390 \mu$ atm (Evans et al., 2011), the seawater $p \mathrm{CO}_{2}$ in these regions was thus estimated to be $336 \pm 4 \mu \mathrm{atm}$, which agreed 

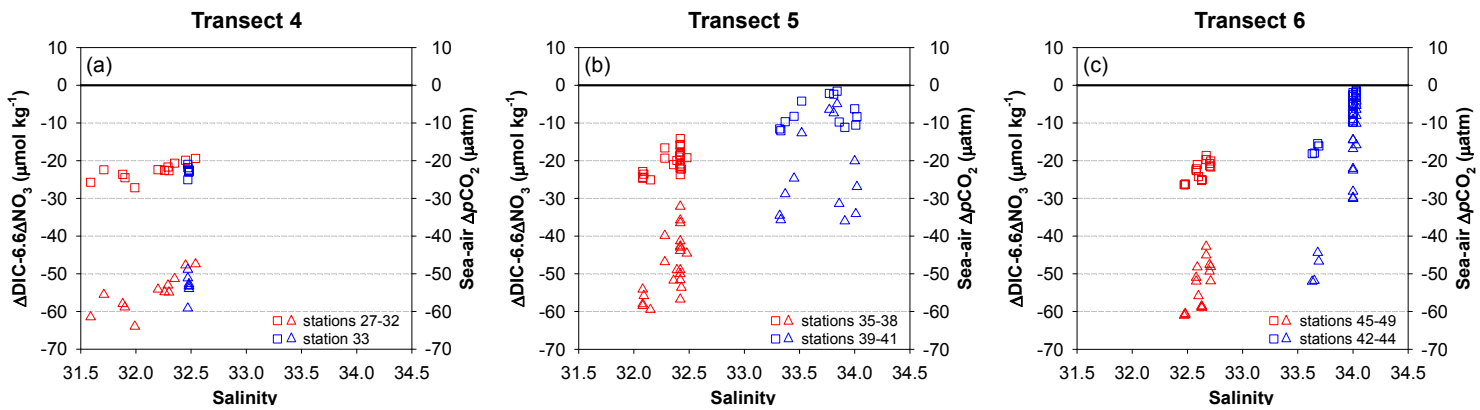

Figure 4. $\Delta \mathrm{DIC}-6.6 \Delta \mathrm{NO}_{3}$ (squares) and sea-air $\Delta p \mathrm{CO}_{2}$ (triangles) versus salinity in the upper waters on transects 4 (a), 5 (b) and 6 (c) off Oregon and northern California in spring/early summer 2007. Note that data for stations 27-32 on transect 4 were obtained from waters immediately below the surface buoyant layer, while data for other stations were obtained from the surface mixed layer. The value of 6.6 is the Redfield C/N uptake ratio (approximately 106/16; Redfield et al., 1963). The solid line indicates the $p \mathrm{CO}_{2}$ equilibrium between the seawater and the atmosphere.

rather well with the field measurements of $334 \pm 13 \mu \mathrm{atm}$ (the underway seawater $p \mathrm{CO}_{2}$ data were not available online but alternatively calculated by applying TAlk and DIC data to the CO2SYS program; Lewis and Wallace, 1998).

The diagnostic approach was not applied to the surface buoyant layer since the aged CR plume might have experienced complex mixing with various surrounding water masses during its transport, as indicated by the scatter TAlk-Sal relationship (Fig. 3a). However, the far-field CR plume is suggested to be a strong sink of atmospheric $\mathrm{CO}_{2}$ due to earlier biological consumption (Evans et al., 2011), which was supported by the observed low $p \mathrm{CO}_{2}$ of $\sim 220-300 \mu \mathrm{atm}$ in the surface buoyant layer on transect 4 . As a consequence, the $\mathrm{CO}_{2}$ sink nature in the upper waters from the outer shelf (the bottom depth of station 27 was $\sim 170 \mathrm{~m}$ ) to the open basin off Newport, Oregon would primarily result from the higher utilization of nutrients relative to DIC based on their concurrent inputs from deep waters. The non-local high productivity in the CR plume could inject even lower $p \mathrm{CO}_{2}$, but this effect would be transitory.

At the innermost station 25 on transect 4 , highly positive values of $\Delta \mathrm{DIC}-6.6 \Delta \mathrm{NO}_{3}$ and sea-air $\Delta p \mathrm{CO}_{2}$ $\left(\sim 82 \mu \mathrm{mol} \mathrm{kg}^{-1}\right.$ and $\sim 157 \mu \mathrm{atm}$, respectively) were obtained for the surface mixed layer of this station, indicating a significant $\mathrm{CO}_{2}$ source. However, the lowest $p \mathrm{CO}_{2}$ value of $\sim 170 \mu \mathrm{atm}$ was observed in these nearshore waters off Oregon. The poor correlation between TAlk and salinity at station 25 (Fig. 3a) might compromise the estimation, whereas the same method (Eqs. 1-5) was successfully applied to other stations on transect 4 with a distinct TAlk-Sal relationship (i.e., the second phase in Fig. 3a). Note that coastal upwelling clearly influenced the bottom water at station 25 as indicated by the comparable salinity and TAlk values to those in offshore $200 \mathrm{~m}$ waters. Instead of being fed by the upwelled deep water, the DIC and nutrients in the surface mixed layer might have originated from horizontal admixture of the surrounding waters. These waters possibly experienced intense diatom blooms due to the fact that the surface silicate concentrations at station 25 were almost zero, which led to the most undersaturated $p \mathrm{CO}_{2}$ condition observed in the upper waters off Oregon.

\subsubsection{Transects 5 and 6}

On transect 5 near the Oregon-California border, the average $\Delta \mathrm{DIC}-6.6 \Delta \mathrm{NO}_{3}$ and sea-air $\Delta p \mathrm{CO}_{2}$ were estimated to be $-20 \pm 3 \mu \mathrm{mol} \mathrm{kg}{ }^{-1}$ and $-48 \pm 8 \mu \mathrm{atm}$ in the surface mixed layer of stations 35-38 (Fig. 4b). Both values were comparable to those obtained from the surface mixed layer of stations $45-49$ on transect $6\left(-23 \pm 3 \mu \mathrm{mol} \mathrm{kg}{ }^{-1}\right.$ and $-53 \pm 6 \mu \mathrm{atm}$, respectively; Fig. 4c) and on transect 4, indicating a similar magnitude of the $\mathrm{CO}_{2}$ sink term in offshore areas along the Oregon and northern California coast during the sampling period. The estimated sea surface $p \mathrm{CO}_{2}$ of $342 \pm 8 \mu$ atm for transect 5 and $337 \pm 6 \mu \mathrm{atm}$ for transect 6 were consistent with the field measurements of $332 \pm 12$ and $346 \pm 12 \mu$ atm in these regions.

The diagnosed $\mathrm{CO}_{2}$ flux in the nearshore was also comparable between transects 5 and 6 . The $\Delta$ DIC $-6.6 \Delta \mathrm{NO}_{3}$ and sea-air $\Delta p \mathrm{CO}_{2}$ in the surface mixed layer of stations 39-44, although still below zero, were obviously higher than those of stations 35-38 on transect 5 and of stations 45-49 on transect 6 (Fig. 4b and c). Such an increase was expected since stations 39-44 were located in the area with the most intensive upwelling, which brought $\mathrm{CO}_{2}$-rich deep waters to the nearshore surface (Feely et al., 2008). However, our estimation suggested a weaker $\mathrm{CO}_{2}$ sink or close to being in equilibrium with the combined estimated sea surface $p \mathrm{CO}_{2}$ of $368 \pm 14 \mu \mathrm{atm}$, whereas the field measurements of $\sim 600-1000 \mu \mathrm{atm}$ indicated that the coastal upwelling zone should be a very strong source of $\mathrm{CO}_{2}$ to the atmosphere.

Therefore, we took a closer look at transect 5: a uniform salinity of $\sim 34.0$ throughout the entire water column was observed at stations 40 and 41 due to the outcrop of the upwelling source water at the surface of the inner shelf 
on transect 5 (Feely et al., 2008). Although salinity in the surface mixed layer at station 39 was lower, around $\sim 33.4$, the dilution effect of rainwater should be negligible. After removing the rainwater from the mixing scheme and calculating $\triangle$ DIC and $\Delta \mathrm{NO}_{3}$ by directly subtracting the fieldobserved value from the end-member value for the upwelling source water (Eqs. 6 and 7; DIC ${ }^{\text {ref }}$ and $\mathrm{NO}_{3}^{\text {ref }}$ were field measurements of $\sim 200 \mathrm{~m}$ water samples at station 39), the $\Delta$ DIC $-6.6 \Delta \mathrm{NO}_{3}$ values were rapidly increased to above zero in the surface mixed layer at stations 39 and 40 , while values at station 41 with a small increase were still overall below zero (Fig. 5a). Correspondingly, the estimated sea surface $p \mathrm{CO}_{2}$ values were higher than the atmospheric $\mathrm{CO}_{2}$ value at stations 39 and 40 while they were slightly lower than that at station 41 . However, these values still largely fell below the field measurements of seawater $p \mathrm{CO}_{2}$, displaying shoreward increasing differences from $\sim 200$ to $\sim 700 \mu \mathrm{atm}$ (Fig. 5b).

$\Delta \mathrm{DIC}=\mathrm{DIC}^{\mathrm{ref}}-\mathrm{DIC}^{\mathrm{meas}}$,

$\Delta \mathrm{NO}_{3}=\mathrm{NO}_{3}^{\mathrm{ref}}-\mathrm{NO}_{3}^{\text {meas }}$.

With or without taking rainwater into account, our diagnostic approach did not work in the nearshore areas with strong upwelling off Oregon and northern California, even though the mixing scheme of this region was in accordance with the OceMar concept. We contend that OceMar assumes a steady state with balanced DIC and nutrients via both physical mixing and biological alterations in comparable timescales. However, the continuous inputs from the coastal upwelling might have led to the accumulation of DIC and nutrients in the nearshore surface, which could not be timely consumed by the phytoplankton community, suggesting a possible nonsteady state. Fassbender et al. (2011) estimated that the age of the surface mixed layer at nearshore stations on transect 5 is only $\sim 0.2$ days, during which the DIC and $\mathrm{NO}_{3}$ consumption via organic carbon production was almost zero, and $\mathrm{CaCO}_{3}$ dissolution contributed a small fraction to the slightly elevated DIC in the upwelled waters. They further predicted that the nearshore surface $p \mathrm{CO}_{2}$ on transect 5 will decrease to levels of $\sim 200 \mu \mathrm{atm}$ in $\sim 30$ days until $\mathrm{NO}_{3}$ exhaustion via continued biological productivity, implying the achievement of a steady state (Fassbender et al., 2011). Minor biological responses during the intensified upwelling period were also observed in summer 2008, allowing highly oversaturated $p \mathrm{CO}_{2}$ surface water to persist on the inner shelf off Oregon for nearly 2 months (Evans et al., 2011). At this point, it is uncertain why there was such a prolonged delay from the phytoplankton community to the persistent source of upwelled DIC and nutrients. Note that under the condition of a more prevailing upwelling-favorable wind as a predicted consequence of climate change (e.g., Snyder et al., 2003; Diffenbaugh et al., 2004; Sydeman et al., 2014), the nearshore
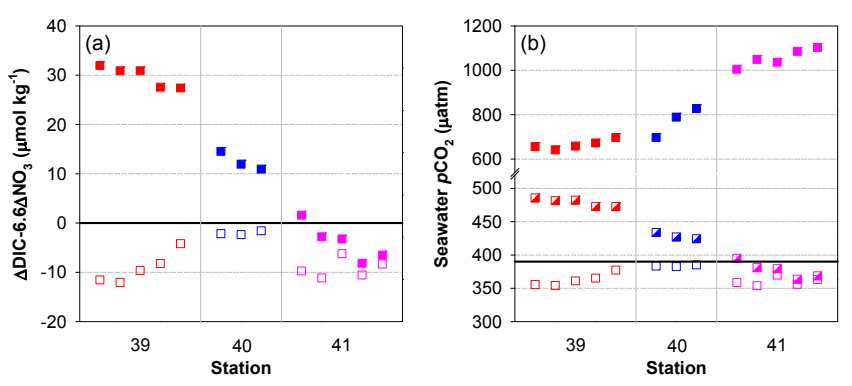

Figure 5. Panel (a) shows $\Delta \mathrm{DIC}-6.6 \Delta \mathrm{NO}_{3}$ and (b) shows seawater $p \mathrm{CO}_{2}$ in the surface mixed layer at stations $39-41$ on transect 5 near the Oregon-California border in spring/early summer 2007. In (a), open symbols indicate values estimated based on the twoend-member mixing between the upwelling source water and the rainwater, while filled symbols indicate values after removing the rainwater. The value of 6.6 is the Redfield $\mathrm{C} / \mathrm{N}$ uptake ratio (approximately 106/16; Redfield et al., 1963). The solid line indicates the $p \mathrm{CO}_{2}$ equilibrium between the seawater and the atmosphere. In (b), the open and semi-filled symbols denote the estimated sea surface $p \mathrm{CO}_{2}$ from $\triangle \mathrm{DIC}-6.6 \Delta \mathrm{NO}_{3}$ on top of the mixing with and without rainwater, respectively. The filled symbols denote the field-observed sea surface $p \mathrm{CO}_{2}$, which were obtained by applying TAlk and DIC data into the CO2SYS program (Lewis and Wallace, 1998). The solid line denotes the atmospheric $p \mathrm{CO}_{2}$ of $\sim 390 \mu \mathrm{atm}$ (Evans et al., 2011).

waters off the Oregon-California coast in the upwelling season might always be in a non-steady state, and it is expected that fewer periodic relaxation events or reversals would further decrease the chance for the biological response to be factored in.

In addition, the negligible biological consumption might involve large errors when calculating $\Delta$. The portion of $\Delta \mathrm{DIC}$ and $\Delta \mathrm{NO}_{3}$ at station 41 relative to the preformed values of the upwelling source water were only $\sim 0.5$ and $\sim 10 \%$, slightly higher than the measurement uncertainties. The portion of DIC and $\mathrm{NO}_{3}$ consumption in the surface mixed layer at offshore stations on transect 5 were, however, 1 order of magnitude higher $(\sim 7$ and $\sim 90 \%$, respectively). This contrast might partially explain why the OceMar framework did not work when insignificant biological alterations occurred. Given the predominant control of physical mixing, we contend that the prediction of the $\mathrm{CO}_{2}$ flux in the nearshore off Oregon and northern California with intensified upwelling could be simplified without considering DIC/nutrient consumption. In other words, surface $\mathrm{CO}_{2}$ levels in this region were simply imprints of the upwelling source water $\left(p \mathrm{CO}_{2} \sim 1000 \mu \mathrm{atm}\right.$ at $\left.\sim 150-200 \mathrm{~m}\right)$ with minor dilution by rainwater.

\subsection{Sensitivity analysis}

In the above exercise, both the end-member values revealed in the water mass mixing scheme and the Redfield ratio adopted in coupling DIC and nutrients were critically 
Table 1. Values of $\Delta \mathrm{DIC}-6.6 \Delta \mathrm{NO}_{3}$, sea-air $\Delta p \mathrm{CO}_{2}$ and sea surface $p \mathrm{CO}_{2}$ estimated with different DIC ${ }^{\text {eff }}$, which is the combined freshwater end member of DIC partly sourced from the Columbia River (CR).

\begin{tabular}{|c|c|c|c|c|c|c|c|c|}
\hline $\begin{array}{l}\text { TAlk/DIC of CR } \\
(\mu \mathrm{mol} \mathrm{kg}-1)\end{array}$ & $\begin{array}{l}\mathrm{NO}_{3} \text { of } \mathrm{CR} \\
(\mu \mathrm{mol} \mathrm{kg}-1)\end{array}$ & $\begin{array}{l}\mathrm{DIC}^{\mathrm{eff}} \\
\left(\mu \mathrm{mol} \mathrm{kg}{ }^{-1}\right)\end{array}$ & \multicolumn{2}{|c|}{$\begin{array}{c}\Delta \mathrm{DIC}-6.6 \Delta \mathrm{NO}_{3} \\
\left(\mu \mathrm{mol} \mathrm{kg}{ }^{-1}\right)\end{array}$} & \multicolumn{2}{|c|}{$\begin{array}{c}\text { Sea-air } \Delta p \mathrm{CO}_{2} \\
\text { ( } \mu \text { atm) }\end{array}$} & \multicolumn{2}{|c|}{$\begin{array}{c}\text { Sea surface } p \mathrm{CO}_{2} \\
(\mu \mathrm{atm})\end{array}$} \\
\hline & & & \multicolumn{2}{|c|}{ Transect 4} & \multicolumn{2}{|c|}{ Transect 4} & \multicolumn{2}{|c|}{ Transect 4} \\
\hline & & & Stations $27-32^{\mathrm{a}}$ & Station $33^{\mathrm{b}}$ & Stations $27-32^{\mathrm{a}}$ & Station $33^{\mathrm{b}}$ & Stations $27-32^{\mathrm{a}}$ & Station $33^{\mathrm{b}}$ \\
\hline 800 & 20 & 420 & $-25 \pm 3$ & $-25 \pm 1$ & $-60 \pm 6$ & $-59 \pm 3$ & $330 \pm 6$ & $331 \pm 3$ \\
\hline 1000 & 15 & 450 & $-23 \pm 2$ & $-23 \pm 1$ & $-55 \pm 5$ & $-53 \pm 3$ & $335 \pm 5$ & $337 \pm 3$ \\
\hline 1200 & 10 & 470 & $-22 \pm 2$ & $-22 \pm 1$ & $-53 \pm 5$ & $-52 \pm 3$ & $337 \pm 5$ & $338 \pm 3$ \\
\hline & & & \multicolumn{2}{|c|}{ Transect 5} & \multicolumn{2}{|c|}{ Transect 5} & \multicolumn{2}{|c|}{ Transect 5} \\
\hline & & & \multicolumn{2}{|c|}{ Stations $35-38^{\mathrm{b}}$} & \multicolumn{2}{|c|}{ Stations $35-38^{\mathrm{b}}$} & \multicolumn{2}{|c|}{ Stations $35-38^{\mathrm{b}}$} \\
\hline 800 & 20 & 540 & \multicolumn{2}{|c|}{$-23 \pm 3$} & \multicolumn{2}{|c|}{$-53 \pm 8$} & \multicolumn{2}{|c|}{$337 \pm 8$} \\
\hline 1000 & 15 & 585 & \multicolumn{2}{|c|}{$-20 \pm 3$} & \multicolumn{2}{|c|}{$-48 \pm 8$} & \multicolumn{2}{|c|}{$342 \pm 8$} \\
\hline 1200 & 10 & 610 & \multicolumn{2}{|c|}{$-19 \pm 3$} & \multicolumn{2}{|c|}{$-46 \pm 8$} & \multicolumn{2}{|c|}{$344 \pm 8$} \\
\hline & & & \multicolumn{2}{|c|}{ Transect 6} & \multicolumn{2}{|c|}{ Transect 6} & \multicolumn{2}{|c|}{ Transect 6} \\
\hline & & & \multicolumn{2}{|c|}{ Stations $45-49^{\mathrm{b}}$} & \multicolumn{2}{|c|}{ Stations $45-49^{\mathrm{b}}$} & \multicolumn{2}{|c|}{ Stations $45-49^{\mathrm{b}}$} \\
\hline 800 & 20 & 500 & \multicolumn{2}{|c|}{$-25 \pm 3$} & \multicolumn{2}{|c|}{$-57 \pm 6$} & \multicolumn{2}{|c|}{$333 \pm 6$} \\
\hline 1000 & 15 & 540 & \multicolumn{2}{|c|}{$-23 \pm 3$} & \multicolumn{2}{|c|}{$-53 \pm 6$} & \multicolumn{2}{|c|}{$337 \pm 6$} \\
\hline 1200 & 10 & 570 & \multicolumn{2}{|c|}{$-22 \pm 3$} & \multicolumn{2}{|c|}{$-51 \pm 6$} & \multicolumn{2}{|c|}{$339 \pm 6$} \\
\hline
\end{tabular}

a Data for these stations were obtained from waters immediately below the surface buoyant layer. ${ }^{\mathrm{b}}$ Data for these stations were obtained from the surface mixed layer.

Table 2. Values of $\triangle \mathrm{DIC}-6.6 \Delta \mathrm{NO}_{3}$, sea-air $\Delta p \mathrm{CO}_{2}$ and sea surface $p \mathrm{CO}_{2}$ estimated with the deep water end member from different depths.

\begin{tabular}{|c|c|c|c|c|c|c|}
\hline \multirow[t]{2}{*}{$\begin{array}{l}\text { Depth of the deep } \\
\text { water end member }(m)\end{array}$} & \multicolumn{2}{|c|}{$\begin{array}{c}\Delta \mathrm{DIC}-6.6 \Delta \mathrm{NO}_{3} \\
\quad\left(\mu \mathrm{mol} \mathrm{kg}{ }^{-1}\right)\end{array}$} & \multicolumn{2}{|c|}{$\begin{array}{c}\text { Sea-air } \Delta p \mathrm{CO}_{2} \\
(\mu \mathrm{atm})\end{array}$} & \multicolumn{2}{|c|}{$\begin{array}{l}\text { Sea surface } p \mathrm{CO}_{2} \\
(\mu \mathrm{atm})\end{array}$} \\
\hline & \multicolumn{2}{|c|}{ Transect 4} & \multicolumn{2}{|c|}{ Transect 4} & \multicolumn{2}{|c|}{ Transect 4} \\
\hline $\begin{array}{l}\sim 130 \\
\sim 150 \\
\sim 175 \\
\sim 200\end{array}$ & $\begin{array}{l}\text { Stations } 27-32^{a} \\
-23 \pm 2 \\
-23 \pm 2 \\
-23 \pm 2 \\
-23 \pm 2\end{array}$ & $\begin{array}{l}\text { Station } 33^{b} \\
-19 \pm 1 \\
-22 \pm 1 \\
-23 \pm 1 \\
-24 \pm 1\end{array}$ & $\begin{array}{l}\text { Stations } 27-32^{\mathrm{a}} \\
-56 \pm 5 \\
-55 \pm 5 \\
-55 \pm 5 \\
-55 \pm 5\end{array}$ & $\begin{array}{l}\text { Station } 33^{b} \\
-45 \pm 3 \\
-52 \pm 3 \\
-53 \pm 3 \\
-56 \pm 3\end{array}$ & $\begin{array}{l}\text { Stations } 27-32^{\mathrm{a}} \\
334 \pm 5 \\
335 \pm 5 \\
335 \pm 5 \\
335 \pm 5\end{array}$ & $\begin{array}{l}\text { Station } 33^{b} \\
345 \pm 3 \\
338 \pm 3 \\
337 \pm 3 \\
334 \pm 3\end{array}$ \\
\hline & \multicolumn{2}{|c|}{ Transect 5} & \multicolumn{2}{|c|}{ Transect 5} & \multicolumn{2}{|c|}{ Transect 5} \\
\hline $\begin{array}{l}\sim 130 \\
\sim 150 \\
\sim 175 \\
\sim 200\end{array}$ & $\begin{array}{r}\text { Stations } \\
-21= \\
-20 \\
-20 \\
-17\end{array}$ & $\begin{array}{l}-38^{\mathrm{b}} \\
3 \\
3 \\
3 \\
3\end{array}$ & $\begin{array}{r}\text { Stations } \\
-51= \\
-46 \\
-48 \\
-40\end{array}$ & $\begin{array}{l}-38^{\mathrm{b}} \\
8 \\
8 \\
8 \\
8\end{array}$ & $\begin{array}{r}\text { Stations } \\
339= \\
344= \\
342= \\
350=\end{array}$ & $-38^{\mathrm{b}}$ \\
\hline & \multicolumn{2}{|c|}{ Transect 6} & \multicolumn{2}{|c|}{ Transect 6} & \multicolumn{2}{|c|}{ Transect 6} \\
\hline $\begin{array}{l}\sim 130 \\
\sim 150 \\
\sim 175 \\
\sim 200\end{array}$ & $\begin{array}{r}\text { Stations } \\
-20= \\
-22= \\
-23= \\
-21=\end{array}$ & $\begin{array}{l}-49^{b} \\
3 \\
3 \\
3 \\
3\end{array}$ & $\begin{array}{r}\text { Stations } \\
-46= \\
-51= \\
-53= \\
-50=\end{array}$ & $\begin{array}{l}-49^{b} \\
6 \\
6 \\
6 \\
6\end{array}$ & $\begin{array}{r}\text { Stations } \\
344= \\
339= \\
337= \\
340=\end{array}$ & $\frac{-49^{b}}{5}$ \\
\hline
\end{tabular}

${ }^{a}$ Data for these stations were obtained from waters immediately below the surface buoyant layer. ${ }^{b}$ Data for these stations were obtained from the surface mixed layer. 
important in resolving the $\mathrm{CO}_{2}$ fluxes. We thus conducted a sensitivity analysis for these two sets of variables for the $\mathrm{CO}_{2}$ sink zones off Oregon and northern California where our diagnostic approach worked well (i.e., waters immediately below the surface buoyant layer at stations $27-32$ as well as waters in the surface mixed layer at station 33 on transect 4 , waters in the surface mixed layer at stations $35-38$ on transect 5 and waters in the surface mixed layer at stations $45-49$ on transect 6).

\subsubsection{The combined freshwater end member}

While the values of $\sim 1000$ and $\sim 15 \mu \mathrm{mol} \mathrm{kg}{ }^{-1}$ were selected for TAlk/DIC and $\mathrm{NO}_{3}$ in the mainstream of the CR, the field-observed TAlk and $\mathrm{NO}_{3}$ vary within a range of $\sim 800-1200$ (Evans et al., 2013) and $\sim 10-20 \mu \mathrm{mol} \mathrm{kg}^{-1}$ (http://www.stccmop.org/datamart/) in spring/early summer. We thus took the values of $\sim 800$ and $\sim 1200 \mu \mathrm{mol} \mathrm{kg}^{-1}$ as the lower and upper limit of the TAlk and DIC end members and those of $\sim 10$ and $\sim 20 \mu \mathrm{mol} \mathrm{kg}{ }^{-1}$ as the lower and upper limit of the $\mathrm{NO}_{3}$ end member in the $\mathrm{CR}$ to test the diagnostic approach. Following the same calculation of the combined freshwater end member ( $X^{\text {eff }}$ in Eq. 3), the lower and upper limit of DIC ${ }^{\text {eff }}$ was estimated to be $\sim 420$ and $\sim 470 \mu \mathrm{mol} \mathrm{kg}^{-1}$ for waters immediately below the surface buoyant layer at stations 27-32 and in the surface mixed layer at station 33 on transect 4 . Those values were $\sim 540$ and $\sim 610 \mu \mathrm{mol} \mathrm{kg}^{-1}$ for waters in the surface mixed layer at stations $35-38$ on transect 5 , and $\sim 500$ and $\sim 570 \mu \mathrm{mol} \mathrm{kg}-1$ in the surface mixed layer at stations $45-49$ on transect 6 . The $\mathrm{NO}_{3}^{\text {eff }}$ in every scenario was still zero.

The newly diagnosed $\triangle \mathrm{DIC}-6.6 \Delta \mathrm{NO}_{3}$ and sea-air $\Delta p \mathrm{CO}_{2}$ on transects 4,5 and 6 displayed no difference with those with the initial TAlk and DIC of $\sim 1000 \mu \mathrm{mol} \mathrm{kg}^{-1}$ and $\mathrm{NO}_{3}$ of $\sim 15 \mu \mathrm{mol} \mathrm{kg}^{-1}$ in the CR (Table 1), while all estimated sea surface $p \mathrm{CO}_{2}$ values were within error (1 standard deviation) compared to the field measurements. Although the TAlk and DIC end members had large variations of up to $\sim 400 \mu \mathrm{mol} \mathrm{kg}^{-1}$ while $\mathrm{NO}_{3}$ varied within $\sim 10 \mu \mathrm{mol} \mathrm{kg}-1$ in the mainstream of the $\mathrm{CR}$, the corresponding range of DIC ${ }^{\text {eff }}$ contributing to waters beyond the CR plume significantly decreased by approximately 1 order of magnitude, implying minor influence of its variations on our diagnosis of the $\mathrm{CO}_{2}$ fluxes.

\subsubsection{The deep water end member}

We selected values at $\sim 175 \mathrm{~m}$ as the deep water end member based on the TAlk-Sal relationship, whereas this end member depth might not be spatially stable in a highly dynamic upwelling system. Previous studies also show that the upwelling source water on the Oregon-California shelf can vary between 150 and $200 \mathrm{~m}$ (e.g., Hales et al., 2005; Feely et al., 2008). We thus tested the diagnostic approach with values at three other depths of $\sim 130, \sim 150$ and $\sim 200 \mathrm{~m}$.
On transects 4 and 6 , the newly estimated $\Delta$ DIC- $6.6 \Delta \mathrm{NO}_{3}$, sea-air $\Delta p \mathrm{CO}_{2}$ and sea surface $p \mathrm{CO}_{2}$ using end-member values at both $\sim 150$ and $\sim 200 \mathrm{~m}$ agreed well with those using end-member values at $\sim 175 \mathrm{~m}$, while the three variables were slightly higher using end-member values at $\sim 130 \mathrm{~m}$ (Table 2). On transect 5 , the newly estimated $\Delta \mathrm{DIC}-6.6 \Delta \mathrm{NO}_{3}$, sea-air $\Delta p \mathrm{CO}_{2}$ and sea surface $p \mathrm{CO}_{2}$ using end-member values at both $\sim 130$ and $\sim 150 \mathrm{~m}$ agreed well with those using end-member values at $\sim 175 \mathrm{~m}$, while the three variables were slightly higher using end-member values at $\sim 200 \mathrm{~m}$ (Table 2 ).

\subsubsection{The $\mathrm{C} / \mathrm{N}$ uptake ratio}

In a given oceanic setting, the real $\mathrm{C} / \mathrm{N}$ uptake ratio during organic carbon production can be different from the Redfield stoichiometry of $\sim 6.6$ (Redfield et al., 1963). For instance, higher ratios estimated from the DIC- $\mathrm{NO}_{3}$ relationship are observed in both coastal waters and open ocean sites, possibly resulting from excess DIC uptake via the production of dissolved organic carbon (Sambrotto et al., 1993; Ianson et al., 2003). However, since the precise estimation of the $\mathrm{C} / \mathrm{N}$ uptake ratio (via, for example, in situ incubation experiments) is still problematic, such data are currently scarce over the world's oceans, and the empirical stoichiometry is routinely applied into field studies investigating the dynamics and coupling of carbon and nutrients (e.g., Chen et al., 2008; Fassbender et al., 2011). Fassbender et al. (2011) applied another empirical $\mathrm{C} / \mathrm{N}$ uptake ratio of 7.3 (approximately 117/16; Anderson and Sarmiento, 1994) into the same data set as this study. We thus performed a simple sensitivity analysis using this alternative value of 7.3, which implies excess DIC uptake relative to $\mathrm{NO}_{3}$.

Since $\triangle \mathrm{DIC}-7.3 \Delta \mathrm{NO}_{3}$ values were obviously smaller than $\Delta$ DIC- $6.6 \Delta \mathrm{NO}_{3}$ ones, the new sea-air $\Delta p \mathrm{CO}_{2}$ values were halved (Table 3 ). Correspondingly, the newly estimated sea surface $p \mathrm{CO}_{2}$ values on transects 4,5 and 6 were $\sim 35-45 \mu \mathrm{atm}$ lower than the estimation using the Redfield ratio, which were however consistent with the field measurements. Given that the Redfield ratio also works in our OceMar case studies of the SCS and the CS (Dai et al., 2013), we contend that this classic ratio could be preferentially employed if the field-observed elemental stoichiometry is not available. Moreover, as Martz et al. (2014) pointed out, "treating the Redfield ratios as global or regional constants may be acceptable in the context of interpreting snapshots of the water column captured in shipboard bottle data".

The above notion was also supported by examining the slope of the linear regression between DIC and $\mathrm{NO}_{3}$ normalized to a constant salinity in the surface water or in the surface mixed layer, which provides an alternative to the $\mathrm{C} / \mathrm{N}$ uptake ratio associated with organic carbon production (Sambrotto et al., 1993; Wong et al., 2002; Ianson et al., 2003). Given a nonzero combined freshwater end member, we adopted in this study an approach of regional 
Table 3. Values of sea-air $\Delta p \mathrm{CO}_{2}$ and sea surface $p \mathrm{CO}_{2}$ estimated with different $\Delta \mathrm{DIC}-x \Delta \mathrm{NO}_{3}$. The variable $x$ denotes the $\mathrm{C} / \mathrm{N}$ uptake ratio during organic carbon production. $T$ and $S$ represent transect and station(s).

\begin{tabular}{|c|c|c|c|c|c|c|c|c|c|c|c|c|}
\hline \multirow[t]{3}{*}{$\begin{array}{l}\mathrm{C} / \mathrm{N} \\
\text { uptake ratio }\end{array}$} & \multicolumn{4}{|c|}{$\begin{array}{c}\Delta \mathrm{DIC}-x \Delta \mathrm{NO}_{3} \\
\left(\mu \mathrm{mol} \mathrm{kg}{ }^{-1}\right)\end{array}$} & \multicolumn{4}{|c|}{$\begin{array}{c}\text { Sea-air } \Delta p \mathrm{CO}_{2} \\
(\mu \mathrm{atm})\end{array}$} & \multicolumn{4}{|c|}{$\begin{array}{c}\text { Sea surface } p \mathrm{CO}_{2} \\
(\mu \mathrm{atm})\end{array}$} \\
\hline & \multicolumn{2}{|c|}{$T 4$} & \multirow{2}{*}{$\frac{T 5}{S 35-38^{\mathrm{b}}}$} & \multirow{2}{*}{$\begin{array}{c}T 6 \\
S 45-49^{\mathrm{b}}\end{array}$} & \multicolumn{2}{|c|}{$T 4$} & \multirow{2}{*}{$\frac{T 5}{S 35-38^{\mathrm{b}}}$} & \multirow{2}{*}{$\frac{T 6}{S 45-49^{\mathrm{b}}}$} & \multicolumn{2}{|c|}{$T 4$} & \multirow{2}{*}{$\frac{T 5}{S 35-38^{\mathrm{b}}}$} & \multirow{2}{*}{$\frac{T 6}{S 45-49^{\mathrm{b}}}$} \\
\hline & $S 27-32^{\mathrm{a}}$ & $S 33^{\mathrm{b}}$ & & & $S 27-32^{\mathrm{a}}$ & $S 33^{\mathrm{b}}$ & & & $S 27-32^{\mathrm{a}}$ & $S 33^{\mathrm{b}}$ & & \\
\hline $6.6^{\mathrm{c}}$ & $-23 \pm 2$ & $-23 \pm 1$ & $-20 \pm 3$ & $-23 \pm 3$ & $-55 \pm 5$ & $-53 \pm 3$ & $-48 \pm 8$ & $-53 \pm 6$ & $335 \pm 5$ & $337 \pm 3$ & $342 \pm 8$ & $337 \pm 6$ \\
\hline $7.3^{\mathrm{d}}$ & $-42 \pm 3$ & $-42 \pm 1$ & $-39 \pm 3$ & $-42 \pm 3$ & $-101 \pm 6$ & $-100 \pm 3$ & $-92 \pm 8$ & $-97 \pm 6$ & $289 \pm 6$ & $290 \pm 3$ & $298 \pm 8$ & $293 \pm 6$ \\
\hline
\end{tabular}

${ }^{a}$ Data for these stations were obtained from waters immediately below the surface buoyant layer. ${ }^{b}$ Data for these stations were obtained from the surface mixed layer. c 6.6 is the Redfield C/ N uptake ratio (approximately 106/16; Redfield et al., 1963). ${ }^{\mathrm{d}} 7.3$ is the more recent evaluation of the C/ $\mathrm{N}$ uptake ratio (approximately $117 / 16$; Anderson and Sarmiento, 1994).

normalization (Friis et al., 2003; Cao et al., 2011) as:

$n X=\frac{X^{\text {meas }}-X^{\text {eff }}}{\text { Sal }^{\text {meas }}} \cdot \mathrm{Sal}^{\text {aver }}+X^{\text {eff }}$.

Here, $n X$ and $X^{\text {meas }}$ are salinity-normalized and fieldmeasured values for DIC and $\mathrm{NO}_{3}$. Sal ${ }^{\text {meas }}$ is the CTDmeasured salinity. Sal ${ }^{\text {aver }}$ is the average salinity value of $\sim 33.0$ in these $\mathrm{CO}_{2}$ sink zones, which was selected as the constant salinity. $X^{\text {eff }}$ is the same as that in Eq. (3), denoting the effective concentration of DIC or $\mathrm{NO}_{3}$ sourced from the freshwater input to various zones off Oregon and northern California. While the $\mathrm{NO}_{3}^{\text {eff }}$ in any combined freshwater end member was zero, the DIC ${ }^{\text {eff }}$ was $\sim 450 \mu \mathrm{mol} \mathrm{kg}^{-1}$ for waters immediately below the surface buoyant layer at stations $27-32$ and waters in the surface mixed layer at stations 25 and 33 on transect $4, \sim 585 \mu \mathrm{mol} \mathrm{kg}{ }^{-1}$ for waters in the surface mixed layer at stations $35-38$ on transect 5, and $\sim 540 \mu \mathrm{mol} \mathrm{kg}^{-1}$ for waters in the surface mixed layer at stations 45-49 on transect 6 .

As shown in Fig. 6, our analysis with all data from the $\mathrm{CO}_{2}$ sink zones along the three transects revealed a slope of $6.70 \pm 0.37$. This value was within error comparable to that of 6.6, suggesting that using the Redfield ratio in our diagnostic approach should be in order. On the other hand, we contend that scrutinizing the in situ $\mathrm{C} / \mathrm{N}$ uptake ratio via relatively direct observations is imperative for better understanding the issue regarding the possible departure from the Redfield ratio.

\section{Concluding remarks}

The semi-analytical diagnostic approach of mass balance that couples physical transport and biogeochemical alterations was well applied to the $\mathrm{CO}_{2}$ sink zones off Oregon and northern California in spring/early summer 2007, extending from the outer shelf to the open basin. In these zones with the absence of any significant influence of the CR plume, the source of DIC was largely from deep waters in the subtropical gyre of the eNP, and the ultimate $\mathrm{CO}_{2}$ sink nature was determined by the higher nutrient consumption than DIC in the upper waters. On the other hand, the estimated $\mathrm{CO}_{2}$ flux was

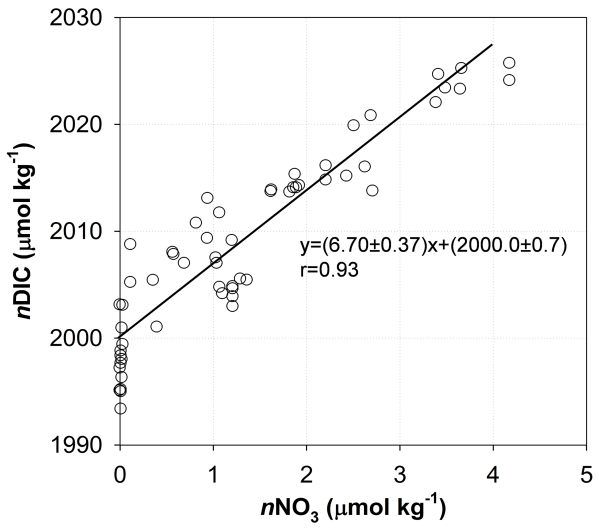

Figure 6. Salinity-normalized DIC $(n$ DIC) versus salinitynormalized $\mathrm{NO}_{3}\left(n \mathrm{NO}_{3}\right)$ in the $\mathrm{CO}_{2}$ sink zones off Oregon and northern California in spring/early summer 2007, which included waters immediately below the surface buoyant layer at stations 27-32 as well as waters in the surface mixed layer at station 33 on transect 4, waters in the surface mixed layer at stations 35-38 on transect 5 and waters in the surface mixed layer at stations $45-49$ on transect 6 .

opposite the field observations in the nearshore upwelling zone along the Oregon-California coast, which behaved like a typical OceMar system in terms of its mixing process. This discrepancy was very likely due to minor biological responses during the intensified upwelling period, making our mass balance approach based on the coupled physical biogeochemistry invalid. This suggested that the applicability of the proposed semi-analytical diagnostic approach is limited to steady state systems with comparable timescales of water mass mixing and biogeochemical reactions. In a physical mixing prevailing regime, resolving the $\mathrm{CO}_{2}$ fluxes could instead be simplified without considering the biological consumption of DIC and nutrients. Further work is however required to better understand the carbon and nutrient dynamics and the timing of the physical and biological processes associated with coastal upwelling. 
Acknowledgements. This work was funded by the National Key Scientific Research Project (no. 2015CB954000) and the National Basic Research Program (973) (no. 2009CB421200) sponsored by the Ministry of Science and Technology of the PRC. This work was also supported by the National Natural Science Foundation of China through grants 91328202, 41121091, 90711005 and 41130857. We are very grateful to the Carbon Dioxide Information Analysis Center (CDIAC; http://cdiac.ornl.gov/oceans/) for the online-published data of the first North American Carbon Program (NACP) West Coast Cruise. Z. Cao is supported by the Humboldt Research Fellowship for postdoctoral researchers provided by the Alexander von Humboldt Foundation. We thank John Hodgkiss for his help with the manuscript's English. Comments from Rik Wanninkhof, Debby Ianson and another anonymous reviewer have significantly improved the quality of the paper.

Edited by: K. Fennel

\section{References}

Aguilar-Islas, A. M. and Bruland, K. W.: Dissolved manganese and silicic acid in the Columbia River plume: A major source to the California current and coastal waters off Washington and Oregon, Mar. Chem., 101, 233-247, 2006.

Allen, J. S., Newberger, P. A., and Federiuk, J.: Upwelling circulation on the Oregon continental shelf, Part I: Response to idealized forcing, J. Phys. Oceanogr., 25, 1843-1866, 1995.

Anderson, L. A. and Sarmiento, J. L.: Redfield ratios of remineralization determined by nutrient data analysis, Global Biogeochem. Cy., 8, 65-80, 1994.

Barth, J. A. and Smith, R. L.: Separation of a coastal upwelling jet at Cape Blanco, Oregon, USA, in: Benguela Dynamics: Impacts of Variability on Shelf-Sea Environments and their Living Resources, edited by: Pillar, S. C., Moloney, C. L., Payne, A. I. L., and Shillington, F. A., S. Afr. J. Mar. Sci., 19, 5-14, 1998.

Barth, J. A., Pierce, S. D., and Smith, R. L.: A separating coastal upwelling jet at Cape Blanco, Oregon and its connection to the California Current System, Deep-Sea Res. Pt. II, 47, 783-810, 2000.

Borges, A. V.: Present day carbon dioxide fluxes in the coastal ocean and possible feedbacks under global change, in: Oceans and the Atmospheric Carbon Content, edited by: Duarte, P. and SantanaCasiano, J. M., Springer Science+Business Media B.V., chap. 3, 47-77, 2011.

Borges, A. V. and Frankignoulle, M.: Distribution of surface carbon dioxide and air-sea exchange in the upwelling system off the Galician coast, Global Biogeochem. Cy., 16, 13-1-13-13, doi:10.1029/2000GB001385, 2002.

Borges, A. V., Delille, B., and Frankignoulle, M.: Budgeting sinks and sources of $\mathrm{CO}_{2}$ in the coastal ocean: Diversity of ecosystems counts, Geophys. Res. Lett., 32, L14601, doi:10.1029/2005GL023053, 2005.

Cai, W.-J.: Estuarine and coastal ocean carbon paradox: $\mathrm{CO}_{2}$ sinks or sites of terrestrial carbon incineration?, Annu. Rev. Mar. Sci., 3, 123-145, 2011.

Cai, W.-J., Dai, M., and Wang, Y.: Air-sea exchange of carbon dioxide in ocean margins: A province-based synthesis, Geophys. Res. Lett., 33, L12603, doi:10.1029/2006GL026219, 2006.
Cao, Z., Dai, M., Zheng, N., Wang, D., Li, Q., Zhai, W., Meng, F., and Gan, J.: Dynamics of the carbonate system in a large continental shelf system under the influence of both a river plume and coastal upwelling, J. Geophys. Res., 116, G02010, doi:10.1029/2010JG001596, 2011.

Castro, C. G., Chavez, F. P., and Collins, C. A.: Role of the California Undercurrent in the export of denitrified waters from the eastern tropical North Pacific, Global Biogeochem. Cy., 15, 819-830, doi:10.1029/2000GB001324, 2001.

Chen, C.-T. A. and Borges, A. V.: Reconciling opposing views on carbon cycling in the coastal ocean: Continental shelves as sinks and near-shore ecosystems as sources of atmospheric $\mathrm{CO}_{2}$, Deep-Sea Res. Pt. II, 56, 578-590, 2009.

Chen, F., Cai, W.-J., Wang, Y., Rii, Y. M., Bidigare, R. R., and Benitez-Nelson, C. R.: The carbon dioxide system and net community production within a cyclonic eddy in the lee of Hawaii, Deep-Sea Res. Pt. II, 55, 1412-1425, 2008.

Colbert, D. and McManus, J.: Nutrient biogeochemistry in an upwelling-influenced estuary of the Pacific Northwest (Tillamook Bay, Oregon, USA), Estuaries, 26, 1205-1219, 2003.

Dai, M., Cao, Z., Guo, X., Zhai, W., Liu, Z., Yin, Z., Xu, Y., Gan, J., Hu, J., and Du, C.: Why are some marginal seas sources of atmospheric $\mathrm{CO}_{2}$ ?, Geophys. Res. Lett., 40, 2154-2158, doi:10.1002/grl.50390, 2013.

Diffenbaugh, N. S., Snyder, M. A., and Sloan, L. C.: Could $\mathrm{CO}_{2}$-induced land-cover feedbacks alter near-shore upwelling regimes?, Proc. Natl. Acad. Sci. USA, 101, 27-32, 2004.

Evans, W., Hales, B., and Strutton, P. G.: Seasonal cycle of surface ocean $p \mathrm{CO}_{2}$ on the Oregon shelf, J. Geophys. Res., 116, C05012, doi:10.1029/2010JC006625, 2011.

Evans, W., Hales, B., Strutton, P. G., and Ianson, D.: Sea-air $\mathrm{CO}_{2}$ fluxes in the western Canadian coastal ocean, Prog. Oceanogr., 101, 78-91, 2012.

Evans, W., Hales, B., and Strutton, P. G.: $p \mathrm{CO}_{2}$ distributions and air-water $\mathrm{CO}_{2}$ fluxes in the Columbia River estuary, Estuar. Coast. Shelf Sci., 117, 260-272, 2013.

Fassbender, A. J., Sabine, C. L., Feely, R. A., Langdon, C., and Mordy, C. W.: Inorganic carbon dynamics during northern California coastal upwelling, Cont. Shelf Res., 31, 1180-1192, 2011.

Federiuk, J. and Allen, J. S.: Upwelling circulation on the Oregon continental shelf. Part II: Simulations and comparisons with observations, J. Phys. Oceanogr., 25, 1867-1889, 1995.

Feely, R. and Sabine, C.: Carbon dioxide and hydrographic measurements during the 2007 NACP West Coast Cruise, http: //cdiac.ornl.gov/ftp/oceans/NACP_West_Coast_Cruise_2007/, Carbon Dioxide Information Analysis Center, Oak Ridge National Laboratory, US Department of Energy, Oak Ridge, Tennessee, 2011.

Feely, R. A., Sabine, C. L., Hernandez-Ayon, J. M., Ianson, D., and Hales, B.: Evidence for upwelling of corrosive "acidified" water onto the continental shelf, Science, 320, 1490-1492, 2008.

Fransson, A., Chierici, M., and Nojiri, Y.: Increased net $\mathrm{CO}_{2}$ outgassing in the upwelling region of the southern Bering Sea in a period of variable marine climate between 1995 and 2001, J. Geophys. Res., 111, C08008, doi:10.1029/2004JC002759, 2006.

Friederich, G. E., Walz, P. M., Burczynski, M. G., and Chavez, F. P.: Inorganic carbon in the central California upwelling system during the 1997-1999 El Niño-La Niña event, Prog. Oceanogr., 54, 185-203, 2002. 
Friis, K., Körtzinger, A., and Wallace, D. W. R.: The salinity normalization of marine inorganic carbon chemistry data, Geophys. Res. Lett., 30, 1085, doi:10.1029/2002GL015898, 2003.

Gan, J. and Allen, J. S.: A modeling study of shelf circulation off northern California in the region of the Coastal Ocean Dynamics Experiment, response to relaxation of upwelling, J. Geophys. Res., 107, 3123, doi:10.1029/2000JC000768, 2002.

Gan, J., and Allen, J. S.: Modeling upwelling circulation off the Oregon coast, J. Geophys. Res., 110, C10S07, doi:10.1029/2004JC002692, 2005.

Hales, B., Takahashi, T., and Bandstra, L.: Atmospheric $\mathrm{CO}_{2}$ uptake by a coastal upwelling system, Global Biogeochem. Cy., 19, GB1009, doi:10.1029/2004GB002295, 2005.

Hales, B., Struttong, P. G., Saraceno, M., Letelier, R., Takahashi, T., Feely, R., Sabine, C., and Chavez, F.: Satellite-based prediction of $p \mathrm{CO}_{2}$ in coastal waters of the eastern North Pacific, Prog. Oceanogr., 103, 1-15, 2012.

Hickey, B. M.: Patterns and processes of circulation over the Washington continental shelf and slope, in: Coastal Oceanography of Washington and Oregon, Elsevier Sci., New York, 47, 41-115, doi:10.1016/S0422-9894(08)70346-5, 1989.

Hill, J. K. and Wheeler, P. A.: Organic carbon and nitrogen in the northern California current system: comparison of offshore, river plume, and coastally upwelled waters, Prog. Oceanogr., 53, 369-387, 2002.

Huyer, A.: Coastal upwelling in the California Current system, Prog. Oceanogr., 12, 259-284, 1983.

Ianson, D., Allen, S. E., Harris, S. L., Orians, K. J., Varela, D. E., and Wong, C. S.: The inorganic carbon system in the coastal upwelling region west of Vancouver Island, Canada, Deep-Sea Res. I, 50, 1023-1042, 2003.

Kosro, P. M., Huyer, A., Ramp, S. R., Smith, R. L., Chavez, F. P., Cowles, T. J., Abbott, M. R., Strub, P. T., Barber, R. T., Jessen, P., and Small, L. F.: The structure of the transition zone between coastal waters and the open ocean off northern California, winter and spring 1987, J. Geophys. Res., 96, 14707-14730, 1991.

Laruelle, G. G., Dürr, H. H., Slomp, C. P., and Borges, A. V.: Evaluation of sinks and sources of $\mathrm{CO}_{2}$ in the global coastal ocean using a spatially-explicit typology of estuaries and continental shelves, Geophys. Res. Lett., 37, L15607, doi:10.1029/2010GL043691, 2010.

Lewis, E. and Wallace, D. W. R.: Program Developed for $\mathrm{CO}_{2}$ System Calculations, ORNL/CDIAC-105, Carbon Dioxide Information Analysis Center, Oak Ridge National Laboratory, U.S. Department of Energy, Oak Ridge, TN, 1998.

Lohan, M. C. and Bruland, K. W.: The importance of vertical mixing for the supply of nitrate and iron to the Columbia River plume: Implications for biology, Mar. Chem., 98, 260-273, 2006.

Lynn, R. J. and Simpson, J. J.: The California Current system: The seasonal variability of its physical characteristics, J. Geophys. Res., 92, 12947-12966, 1987.

Martz, T., Send, U., Ohman, M. D., Takeshita, Y., Bresnahan, P., Kim, H.-J., and Nam, S. H.: Dynamic variability of biogeochemical ratios in the Southern California Current System, Geophys. Res. Lett., 41, 2496-2501, doi:10.1002/2014GL059332, 2014.
Oke, P. R., Allen, J. S., Miller, R. N., Egbert, G. D., Austin, J. A., Barth, J. A., Boyd, T. J., Kosro, P. M., and Levine, M. D.: A modeling study of the three-dimensional continental shelf circulation off Oregon. Part I: Model-data comparisons, J. Phys. Oceanogr., 32, 1360-1382, 2002.

Park, K.: Columbia River plume identification by specific alkalinity, Limnol. Oceanogr., 11, 118-120, 1966.

Park, K.: Alkalinity and pH off the coast of Oregon, Deep-Sea Res., 15, 171-183, 1968.

Park, P. K., Gordon, L. I., Hager, S. W., and Cissell, M. C.: Carbon dioxide partial pressure in the Columbia river, Science, 166, 867-868, 1969a.

Park, P. K., Webster, G. R., and Yamamoto, R.: Alkalinity budget of the Columbia River, Limnol. Oceanogr., 14, 559-567, 1969b.

Park, P. K., Catalfomo, M., Webster, G. R., and Reid, B. H.: Nutrients and carbon dioxide in the Columbia river, Limnol. Oceanogr., 15, 70-79, 1970.

Redfield, A. C., Ketchum, B. H., and Richards, F. A.: The influence of organisms on the composition of seawater, in: The Sea, edited by: Hill, M. N., Wiley, New York, 26-77, 1963.

Revelle, R. and Suess, H. E.: Carbon dioxide exchange between atmosphere and ocean and the question of an increase of atmospheric $\mathrm{CO}_{2}$ during the past decades, Tellus, 9, 18-27, 1957.

Sambrotto, R. M., Savidge, G., Robinson, C., Boyd, P., Takahashi, T., Karl, D. M., Langdon, C., Chipman, D., Marra, J., and Codispoti, L.: Elevated consumption of carbon relative to nitrogen in the surface ocean, Nature, 363, 248-250, 1993.

Santana-Casiano, J. M., González-Dávila, M., and Ucha, I. R.: Carbon dioxide fluxes in the Benguela upwelling system during winter and spring: A comparison between 2005 and 2006, Deep-Sea Res. Pt. II, 56, 533-541, 2009.

Sigleo, A. C. and Frick, W. E.: Seasonal variations in river flow and nutrient concentrations in a northwestern USA watershed, in: First interagency conference on research in the watersheds, edited by: Renard, K. G., McElroy, S. A., Gburek, W. J., Canfield, H. E., and Scott, R. L., U.S. Department of Agriculture, 370-376, 2003.

Snyder, M. A., Sloan, L. C., Diffenbaugh, N. S., and Bell, J. L.: Future climate change and upwelling in the California Current, Geophys. Res. Lett., 30, 1823, doi:10.1029/2003GL017647, 2003.

Sundquist, E. T., Plummer, L. N., and Wigley, T. M. L.: Carbon dioxide in the ocean surface: The homogenous buffer factor, Science, 204, 1203-1205, 1979.

Sydeman, W. J., García-Reyes, M., Schoeman, D. S., Rykaczewski, R. R., Thompson, S. A., Black, B. A., and Bograd, S. J.: Climate change and wind intensification in coastal upwelling ecosystems, Science, 345, 77-80, 2014.

Thomson, R. E. and Krassovski, M. V.: Poleward reach of the California Undercurrent extension, J. Geophys. Res., 115, C09027, doi:10.1029/2010JC006280, 2010.

Torres, R., Turner, D. R., Rutllant, J., and Lefèvre, N.: Continued $\mathrm{CO}_{2}$ outgassing in an upwelling area off northern Chile during the development phase of El Niño 1997-1998 (July 1997), J. Geophys. Res., 108, 3336, doi:10.1029/2000JC000569, 2003. 
Wetz, M. S., Hales, B., Chase, Z., Wheeler, P. A., and Whitney, M. M.: Riverine input of macronutrients, iron, and organic matter to the coastal ocean off Oregon, U.S.A., during the winter, Limnol. Oceanogr., 51, 2221-2231, 2006.
Wong, C. S., Waser, N. A. D., Nojiri, Y., Whitney, F. A., Page J. S., and Zeng, J.: Seasonal cycles of nutrients and dissolved inorganic carbon at high and mid latitudes in the North Pacific Ocean during the Skaugran cruises: determination of new production and nutrient uptake ratios, Deep-Sea Res. Pt. II, 49, 5317-5338, 2002. 